\title{
Reproductive success and productivity of the Cyprus Wheatear Oenanthe cypriaca, a migratory, island endemic
}

\author{
Marina Xenophontos $^{1} \cdot$ Will Cresswell ${ }^{1}$
}

Received: 15 September 2015/Revised: 4 November 2015/Accepted: 17 December 2015/Published online: 16 January 2016 (C) The Author(s) 2016. This article is published with open access at Springerlink.com

\begin{abstract}
Population dynamics of annually breeding bird species depend crucially on productivity, and so this variation can help us understand the causes of declines in migrant birds. We investigated variation in annual productivity 2010-2012 in the Cyprus Wheatear Oenanthe cypriaca, a small endemic migrant passerine at the National Forest Park (NFP) of Troodos. Clutch size for first nests was usually five, although 0.40 eggs lower in 2011. Nest survival did not vary with year, nesting attempt, or clutch initiation date, but was significantly higher in the chick $(0.96 ; 0.88-0.98,95 \% \mathrm{CI})$ versus the egg stage $(0.74 ; 0.62-0.83,95 \% \mathrm{CI})$. The number of chicks fledged from a successful nest varied with nest type-with first nests and second nests after failure being similar producing $\sim 3-4.5$ chicks dependent on year, and with second nests after success producing $\sim 2$ chicks, independent of year. There were only weak positive or negative effects of clutch initiation date dependent on year, controlling for nest type, and no effects of male age on productivity. After fledging, chicks had a $>95 \%$ chance of surviving the first month, but with a greater probability of one or rarely two chicks per brood dying if fledged later in the season. Renesting rate was significantly different in all years $(26,48$, and $78 \%$ renesting): 2010 had a much lower renesting rate after success with very few second broods ( 29 versus $76 \%$ and $73 \%$ in 2011 and 2012, respectively). Overall productivity per territory did not vary with year with
\end{abstract}

Communicated by F. Bairlein.

Will Cresswell

wrlc@st-and.ac.uk

1 Centre for Biological Diversity, University of St Andrews, Harold Mitchell Building, St Andrews, Fife KY16 9TH, UK
$3.96 \pm 0.09$ SE chicks alive 1 month after fledging. Cyprus Wheatears showed several unusual breeding parameters including a highly variable renesting probability, high nestling, and very high fledgling survival, resulting in exceptionally high productivity. This may be because renesting is constrained by high mid-summer temperatures and low abundance of chick predators.

Keywords Afro-Palearctic migrant · Population dynamics $\cdot$ Nest survival $\cdot$ Fledgling survival

\section{Zusammenfassung}

Reproduktionserfolg und Zahl von Nachkommen des Zypernsteinschmätzers Oenanthe cypriaca, ein Zugvogel und Inselendemit

Die Populationsdynamik von jährlich brütenden Vogelarten hängt wesentlich von der Zahl der Nachkommen ab, und deshalb kann uns diese Variation helfen, die Ursachen für einen Rückgang bei Zugvögeln zu verstehen. Von 2010 bis 2012 untersuchten wir Schwankungenin der jährlichen Zahl der Nachkommen beim Zypernsteinschmätzer (Oenanthe cypriaca), einem kleinen, endemischen, ziehenden Singvogel, im National Forest Park (NFP) im Troodos-Gebirge. Die Gelegegröße für Erstbruten war normalerweise 5 Eier, allerdings im Jahr 2011 um 0,40 Eier geringer. Die Überlebenswahrscheinlichkeit von Nestern unterschied sich nicht zwischen den Jahren, Brutversuch oder Eiablagedatum, war aber im Küken-Stadium $(0,96 ; 0,88-0,98 ; 95 \%$ CI) signifikant höher als im Ei-Stadium (0,74; 0,62-0,83; 95 \%CI). Die Anzahl der flüggen Jungvögel aus einer erfolgreichen Brut unterschied sich zwischen Bruten. Erste Bruten und Nachbruten ähnelten sich mit, abhängig vom Jahr, ca. 3-4,5 Küken; Zweitbruten hatten dagegen zwei Küken, unabhängig vom 
Jahr. Abhängig vom Jahr und kontrolliert für Nesttyp gab es nur schwach positive oder negative Effekte des Eiablagedatums, und keinen Effekt des Alters des Männchens auf die Produktivität. Flügge Jungvögel hatten eine Chance von mehr als $95 \%$, den ersten Monat zu überleben, aber mit einer höheren Wahrscheinlichkeit, dass ein oder selten zwei Vögel pro Brut starben, wenn sie später flügge wurden. Der Anteil von Folgebruten unterschied sich signifikant zwischen den Jahren (26\%, $48 \%$ bzw. $78 \%$ ). 2010 hatte eine sehr viel geringere Rate an Zweitbruten (29\% gegenüber $76 \%$ und $73 \%$ in 2011 bzw. 2012). Die Gesamtzahl an Nachkommen unterschied sich dagegen nicht zwischen den Jahren und betrug durchschnittlich 3,96 $\pm 0,09$ (SE) Jungvögel, die nach dem Flüggewerden mindestens einen Monat überlebten. Zypernsteinschmätzer zeigten einige ungewöhnliche Brutparameter, wie eine sehr variable Rate an Folgebruten Bruten, eine hohe Überlebensrate für Nestlinge und Flügglinge und dadurch außergewöhnlich hohe Produktivität. Die variable Rate an Folgebruten könnte die Folge hoher Temperaturen im Hochsommer sein, die die Brutzahl limitieren. Die hohe Produktivität könnte ihre Ursache in geringer Kükenprädation haben.

\section{Introduction}

Many populations of trans-Saharan Palearctic migrant birds are declining in Europe (Vickery et al. 2014). In contrast, some populations, including Cyprus Wheatears Oenanthe cypriaca remain abundant (Randler et al. 2010). Productivity during their breeding season in Europe is likely to be an important component of migrant population dynamics (Lack 1954; Newton 1998) and so information on productivity and the factors influencing productivity are needed for effective conservation management (Vickery et al. 2014). If we are to understand the causes of population dynamics in migrant birds we need not only to study species in decline, but also those species that have stable or increasing populations: determination of the special factors determining the population dynamics of migrants that are not declining may help inform us of why other species are declining. Cyprus Wheatears have a number of unusual characteristics that may lead to unusual nesting productivity: they are an island endemic restricted to Cyprus and have the smallest European breeding range of any migrant that winters south of the Sahara (Collar 2005, and 6/6 geolocator birds wintered south of the Sahara in 2014, unpublished data), they have very high annual survival and high site fidelity (Xenophontos and Cresswell 2015), and the nestling and adult predator community of Cyprus lacks sparrowhawks Accipiter nisus (Flint and Stewart 1992).
Population dynamics of annually breeding bird species depend crucially on productivity in any year (Lack 1954; Newton 1998). Initial clutch size (Lack 1947) and the survival of eggs, nestlings, and fledged young (Martin 1995) all determine productivity, as does the probability of renesting after success or initial failure (Lack 1954; Bennett and Owens 2002). Nest predation is usually the main determinant of nesting success (Martin 1995). Several studies have found a decline in nest success during the nestling stage (Schaub et al. 1992; Burhans et al. 2002) due to increased cues provided by parents' feeding trips to the nest and nestling noise. The survival rate of chicks just after fledging is also an important component to productivity because post-fledging survival, particularly in the first month, is invariably low, again mainly due to predation (Newton 1998). Although important, assessment of post-fledging survival is difficult because fledglings are hard to detect and follow as they disperse; therefore, there are few estimates (Cox et al. 2014). Brood-parasites can also reduce the breeding success of birds, either by lowering the body condition of the adults, or by lowering the body condition and survival of the chicks (Newton 1998). These factors can all vary within and between years, determining whether overall productivity balances first year and adult survival and so whether the population size changes. We investigated variation in these factors in the Cyprus Wheatear, a small endemic migrant passerine in order to assess how its productivity varies, and to determine whether productivity is sufficient to offset annual survival.

In this study, we measured reproductive success in a colour-ringed population of Cyprus Wheatears over 3 years (2010-2012) from April to August, to determine how productivity arose from variation in clutch size, nest survival, number of fledged chicks, and fledgling survival. Cyprus Wheatears are also likely to be multi-brooded, so we also measured renesting probability. We measured:

1. Clutch size and how it varied with year. We predicted that clutch size would be reasonably constant with year, but would decline as the season progressed as food resources decline seasonally as found for most other passerine species (Perrins 1970).

2. Nest survival rates during the egg and chick stage. We predicted that nest survival would be higher for the eggs than for the chicks because the chick feeding stage is much more conspicuous to nest predators (Cresswell 1997).

3. The number of chicks fledged from successful nests and how it varied between and within years. We predicted that the number of chicks fledged would vary with year, and would decrease with clutch initiation date and for second nests because of annually variable 
predation risk and decreasing food availability within a season, as found for most other passerine species (Lack 1968).

4. Survival of chicks in the first month of fledging. We predicted that survival would be low during this period and fairly uniform regardless of year because fledglings are highly vulnerable to predation as found for most other passerine species (Cox et al. 2014).

5. Renesting probability. We predicted that this would vary between years because of variable annual predation rates and weather conditions, but that the probability of renesting after a successful first nest would not change because renesting rate is always important to maintain productivity in a multi-brooded species (Lack 1954).

6. Productivity per territory (pair) and its variation with year. This is necessary, along with already established survival rates (Xenophontos and Cresswell 2015), to calculate population trajectories.

\section{Methods}

\section{Study site}

The study was conducted from 2009 to 2013 in a 130-ha area at Troodos National Forest Park, Cyprus $\left(34^{\circ} 56^{\prime} 11^{\prime \prime} \mathrm{N}\right.$ $32^{\circ} 51^{\prime} 48^{\prime \prime} \mathrm{E}$ ), at about $1800 \mathrm{~m}$ a.s.l. during the breeding season. The study area was the Artemis Trail with old low density coniferous forest, supporting one of the densest breeding Cyprus Wheatear populations on the island (Flint and Stewart 1992). The National Forest Park of Troodos (NFP of Troodos) is located at the centre of Troodos massif, which ranges from the northwest to the southeast part of Cyprus and covers an area of 9029 ha with highest peak Chionistra reaching $1952 \mathrm{~m}$. The main habitats that characterize the study area are endemic Black Pine Pinus nigra ssp. pallasiana forest, which ranges from $1400 \mathrm{~m}$ to the top of the mountains, and Juniper Woodland Juniperus foetidissima and Serpentinophilous grasslands that are distributed at the highest parts and that occur in openings of the Black Pine forest in the form of small, scattered patches. The understorey of Black Pine consists of Quercus alnifolia, Juniperus oxycedrus, Juniperus foetidissima, Sorbus aria ssp. cretica, Berberis cretica, Arbutus andrachne, Rosa chionistrae, Rosa canina, Cotoneaster racemiflorus var. nummularius, etc. Annual precipitation in the area is very high with more than $1100 \mathrm{~mm}$ recorded, and temperature varies through the year from freezing during winter to a maximum of about $35^{\circ} \mathrm{C}$ during very hot dry summers.

\section{Field methods}

During 2009, a pilot study identified a study area and monitored and mapped territories, but without colourringing of birds. In subsequent years 2010-2012, individuals were colour-ringed when they were actively defending a territory and locations of territories were plotted on maps; 45-69 territories with at least one individual of the pair colour-ringed were intensively monitored annually to record details of breeding. Observation and data recording started around mid-end of March each year when the first individuals arrived at the breeding ground, and regular monitoring continued until the end of August, with sporadic visits until October.

Pairs were marked within their territory, and at least one individual of the pair was coloured-ringed. The study contained 324 individuals that were colour ringed over 2010-2013 (110 males, 91 females, and 123 chicks). Birds were captured with spring traps throughout the season (but especially during arrival and territory establishment for the adults): playback using conspecific song was used to facilitate trapping. Wheatears were ringed with individual combinations of colour rings. Individuals were sexed, and all males were aged as young (1 year old) or adults $(>1$ year old) based on their plumage characteristics (contrast in the coverts so that first year males had brownish greater coverts-visible in the field-whereas adult males had dark, uniform sooty black wing feathers). The age of females was not considered to have been reliably distinguished until late in the study, and so females in the study were all considered unaged.

At each territory during 2010-2012, we recorded arrival dates of individuals and all nesting attempts. Nests and fledglings were found opportunistically through close observation of behaviour such as nest building and feeding chicks. Fledglings were extremely obvious - the number of fledglings was counted immediately after fledging and 1 month afterwards, although frequent visits meant that fledglings and their survival were actually recorded every few days. Records of breeding activities were collected by systematic observation of the behaviour of birds in their territories every second to third day from the beginning of April to the end of August, thus data consisted of occupancy and activities of a pair, nest stages (laying, incubation, hatching, fledglings), nest type (1 first, 2 renest after success, 3 renest after failure), breeding success (successful vs. failed), and male age. Not all territories could be monitored completely, and so complete information is not available for all territories: some nests were not found, and many were found only in the chick stage when they become more conspicuous. Sample sizes vary throughout as a consequence. 
Nests were on the ground in crevices among large rocks. Laying date was determined by direct observation of the first egg laid in a just completed nest, or by back calculation from the hatch date, or occasionally fledging date, based on the mean duration of nestling and egg stage from known nests. Eggs and chicks were counted by direct observation or using an inspection camera on a flexible, meter-long stalk. A nest failure was defined as when a known nest (nest and eggs or chicks being monitored) lost its eggs or chicks and the parents resumed activities consistent with them renesting or stopping breeding. The day of failure was allocated to the mid-point between the last visit when the nest was active and the first visit when the nest was recorded as inactive. Breeding was defined to be successful when fledglings were observed, or intense warning calls of parents after fledging were heard (at $\geq 15$ days after hatching). Immediate dispersal post-fledging was considered unlikely because we recorded no case of a brood and adult disappearing immediately from a focal or adjacent territory area, that were then found in any other territory in the study site (see monitoring of dispersal in Xenophontos and Cresswell 2015). Fledglings were monitored for at least a month after fledging to record number of surviving chicks and the period of feeding by the parents. Chicks were reasonably conspicuous and stayed together in their parents' relatively small territories allowing a reasonable assessment of the number; nevertheless, any estimates we present may be underestimates of survival because of imperfect detectability. Data collection on the number of fledglings surviving was restricted to the central territories of the study area.

\section{Analysis}

We analysed clutch size with respect to year and clutch initiation date using a general linear model (GLM) assuming a normal distribution. Clutch size was only recorded from first nests, and so nest type was not included in the model: the number of chicks fledged likely provided a proxy for clutch size and was available for most nests, so the effects of nest type on clutch size were tested by using the number of chicks fledged (see below).

We analysed nest survival rate with respect to nest stage (egg or chick), year, and nest type using a linear logistic exposure-model (Shaffer 2004; Hazler 2004) with success or failure of a nest offset by the number of days exposure according to the Mayfield method, which accounts for biases due to not finding nests that fail early (Mayfield 1961). We then calculated the overall probability of nest survival for each stage by the daily nest survival probability calculated from this model raised to the power of the number of days duration for each stage (17 days for egg stage and 14 days for chick stage_-see below).
We analysed the number of chicks fledged from successful nests with respect to year, clutch initiation date and nest type using a GLM assuming a normal distribution. The effects of male age were tested only by adding the variable to the final model because of missing values.

We analysed what affected survival of chicks in the first month of fledging with respect to clutch initiation date, year, and nest type, controlling for brood size (number of chicks initially fledged), using a generalised linear model assuming a binomial distribution. Our response variable was whether one or more chicks was lost during the month after fledging - this was effectively whether one chick was lost from a brood because nearly all broods that lost a chick only lost one chick $(N=47$ broods that lost one chick, only $N=6$ broods lost two chicks, $N=130$ that lost none). We adopted this approach because chick survival was so high and a brood level analysis removes issues of predation events or accidents tending affecting chicks within a brood non-independently.

We assessed the overall relative frequency of renesting with year by simple comparison of the number of first and second nests across the 3 years using a Chi square test. We then assessed the relative frequency of renests after a successful first nest by a simple comparison of the number of successful first and second nests across the 3 years using a Chi square test.

We analysed overall productivity - the total number of chicks produced in a year within the same territory (almost always the same pair with occasional switches in one adult of the pair)—with respect to year using a GLM assuming a normal distribution.

Analysis was carried out using R 2.13.1. Interactions were only tested where there was an a priori biological hypothesis to be tested, but some interactions could not be tested because of sample sizes and missing information (e.g. clutch size). Quadratic effects of clutch initiation date were considered because breeding activities may have peaked mid-season rather than at the start: there was no strong evidence for quadratic effects. Full models were simplified by AIC comparison using the information theoretic approach (Burnham and Anderson 2002). Non-significant interactions were removed by default. The top models were then evaluated for both biological and statistical significance. Residuals of the top models met model assumptions reasonably well, as demonstrated by the plot command in $R$ and according to criteria in (Crawley 2007). Figures illustrate the results of models and plot the predicted values (parameter estimates) for the variable of interest, with other variable values set to their median (and so typical) values. Means are given $\pm 1 \mathrm{SE}$ unless otherwise stated.

Throughout, we present results from models without considering repeated measures from the same individuals 
within and between years (some birds renested within a year, and some nested in 2 or 3 separate years), but note that because we consider year and nest stage as fixed effects in all models, this effectively means only one nesting attempt per pair or territory is included in each group. We found no relationship between productivity and annual survival (Xenophontos and Cresswell 2015), so individuals sampled in more than 1 year were unlikely to have biased productivity estimates. To determine if the results were confounded by repeated measures (some birds being better breeders than others), all models were rerun considering individual male identity as a random effect. Mixed models were run using the lme4 library in R, and the additional variance contributed by the random effect was calculated using the lmer Test library. The statistical and biological significance of all results remained the same, so we report the simpler models only, unless including individual male identity also accounted for a significant amount of increased variation. Note that including male identity to control for random effects does not account entirely for repeated measures by the same birds (or territory effects) because not all birds were ringed, or ringed in the first year of the study, and females and males in a pair changed occasionally.

\section{Results}

Clutch size was only recorded for first nests and was usually five eggs (4.91 $\pm 0.06, N=22$-relatively few nests were found during laying so that actual final clutch size could be recorded accurately). There was significant variation in clutch size of first nests with year, although this was fairly small being slightly lower in 2011 (2010, $5.03 \pm 0.25$; 2011, $4.64 \pm 0.23 ; 2012,4.99 \pm 0.21$; with median clutch initiation date of 11th May) controlling for clutch initiation date $(-0.0099 \pm 0.0105)$ : year, $F_{2,18}=3.8, P=0.041$; clutch initiation date, $F_{1,18}=0.9, P=0.36$.

Daily nest survival was higher during the nestling stage $(0.997 ; 0.992-0.999,95 \%$ CI $)$ than the egg stage $(0.982$; $0.971-0.989,95 \%$ CI): nestling stage, $1.70 \pm 0.48$, $z=3.6, \quad P<0.001$. The egg stage duration was $17.0 \pm 0.4$ days $(N=33$ nests monitored from first egg day to hatch), hatchling stage duration was $14.4 \pm 0.2$ days $(N=98$ nests monitored from first day of hatch to fledgling). Overall probability of nest survival was higher during the 14-day duration chick stage (0.96; $0.88-0.98,95 \% \mathrm{CI})$ than the 17 -day duration egg stage $(0.74 ; 0.62-0.83,95 \%$ CI): Fig. 1. Daily nest survival did not vary significantly between years (Fig. 2), or nesting attempts, or with clutch initiation date, controlling for nest stage (Table 1). Most nest failure in our study site resulted from nest predation. It was impossible to determine the

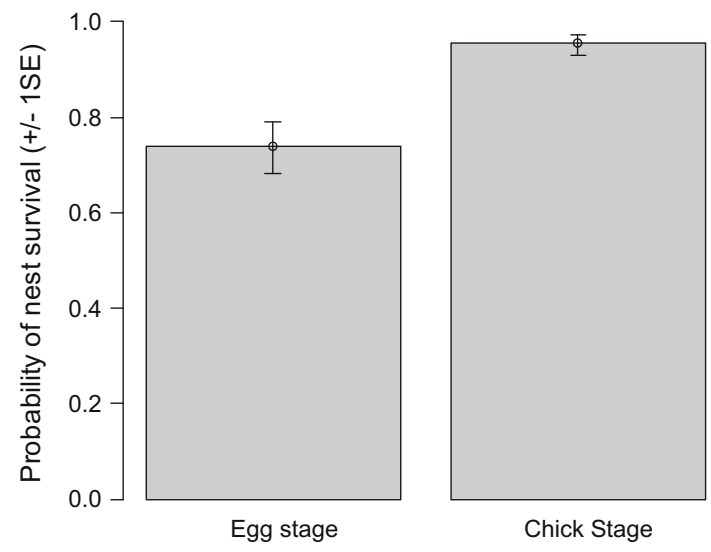

Fig. 1 Predicted overall nest survival ( \pm 1 SE) comparing the egg stage versus the chick stage
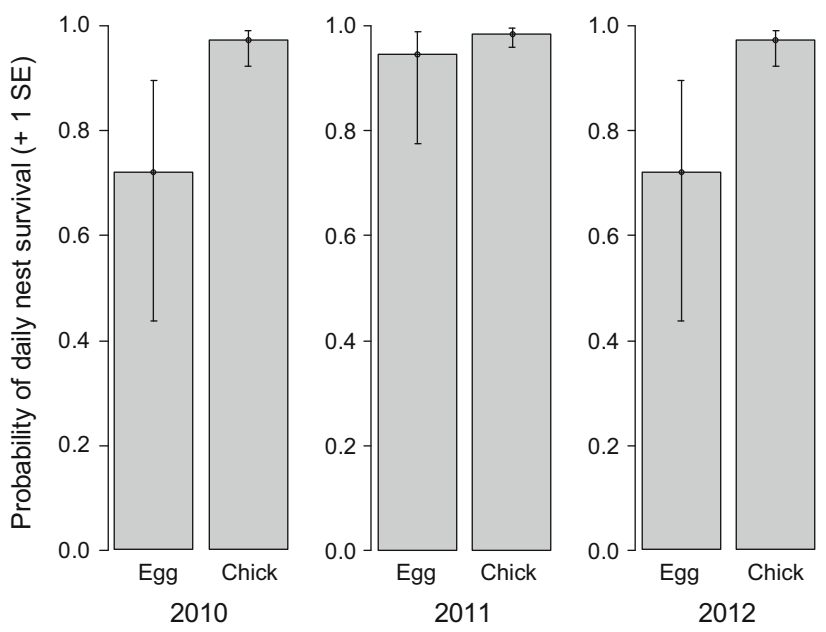

Fig. 2 The probability of a daily nest survival during the egg and chick stage for three breeding seasons (2010-2012) modelled separately (parameter estimates \pm 1 SE for nest stage plotted from the three annual models, daily nest survival $\sim$ nest stage). $2010 N=60$ nests, $2011 N=57$ nests, $2012 N=66$ nests

Table 1 Daily nest survival variation with clutch initiation date, nest stage (egg or chick stage), year (2010-2012), and nest type (first or second nest)

\begin{tabular}{lclcc}
\hline & Estimate & SE & $z$ value & $P$ value \\
\hline (Intercept) $^{\mathrm{a}}$ & 3.1 & 1.0 & 3.1 & 0.002 \\
Clutch initiation date & 0.034 & 0.024 & 1.4 & 0.15 \\
Chick stage & 1.66 & 0.50 & 3.4 & $<0.0001$ \\
2011 & -0.94 & 0.66 & -1.4 & 0.15 \\
2012 & -0.71 & 0.51 & -1.4 & 0.16 \\
2nd nest & -0.69 & 0.95 & -0.7 & 0.47 \\
\hline
\end{tabular}

$N=224$ nests

Interactions were not significant and were removed

$\Delta \mathrm{AIC}+6.3$ with interactions in model

The simplest model only included nest stage $\triangle \mathrm{AIC}-8.8$

a 2010,1st nests and egg stage were set to the intercept 
Table 2 ANOVA table for a model testing predicting the number of fledged chicks by year, nest type and clutch initiation date $\left(F_{11,161}=61.0\right.$, $P<0.001 ; N=173$ broods)

\begin{tabular}{lllcc}
\hline & DOF & Sum of squares & $F$ value & $P$ value \\
\hline Year & 2 & 33.0 & 64.3 & $<0.0001$ \\
Nest type & 2 & 6.7 & 13.2 & $<0.0001$ \\
Clutch initiation date & 1 & 0.69 & 2.7 & 0.10 \\
Year*nest type & 4 & 2.5 & 2.4 & 0.049 \\
Year*clutch initiation date & 2 & 1.8 & 3.6 & 0.031 \\
\hline
\end{tabular}

All interactions were tested, but only significant interactions were retained in the model. The parameter estimates for the effects in separate years are given in Table 3

Main effects only model $\Delta \mathrm{AIC}+22$

Three-way interactions model $\triangle \mathrm{AIC}+6$

All two-way interactions model $\triangle \mathrm{AIC}+3.1$

Addition of clutch initiation date as a quadratic term, or its interaction, in any model $\Delta \mathrm{AIC}>+3.6$

Male age was not significant when added to the model, $-0.086 \pm 0.090, t_{1,136}=-0.01, P=0.34$ identity of the nest predators but potential predators were Cyprus Jays Garrulus glandarius glaszneri that were often observed on the ground near nest sites, lizards (Stellagama stellio cypriaca), mammals (foxes Vulpes vulpes indutus and dogs-some nests were clearly dug up by large mammals—and rodents, probably rats Rattus $\mathrm{sp}$.). One nest in a territory adjacent to the study area in 2011 was parasitized by a Common Cuckoo Cuculus canorus (an adult wheatear was seen feeding a newly fledged cuckoo chick) demonstrating that brood parasitism may also affect nest survival but at a very low frequency (i.e. it was not recorded in the total of 182 fledged broods observed in the 3 years within the study area).

The number of chicks produced by successful nests varied with clutch initiation date and nest type, but these relationships differed with year (i.e. the interactions between year*clutch initiation date and year*nest type were significant: Table 2). We, therefore, considered the effects of clutch initiation date and nest type separately by year (Table 3). Although effect sizes differed with year, there were no significant differences between first nests and second nests after failure $(\sim 3-4.5$ chicks dependent on year), but significantly fewer chicks were produced from second nests after a first successful nest ( $\sim 2$ chicks, independent of year): Table 3 and Fig. 3. There was a small change in number of fledged chicks from successful nests with clutch initiation date, with a negative trend in 2010 and 2011 and a positive trend in 2012 (Table 3; Fig. 4). There was no effect of male age on productivity (Table 2), but sample sizes were small and the confounding effect of female age could not be considered.

There was a relatively high survival rate in the first month after fledging: $71 \%$ of broods lost no chicks, $26 \%$ one chick, and $3 \%$ two chicks ( $N=183$ broods). Therefore, $95.41 \%$ of chicks survived the first month, which is equivalent to a daily survival rate of 0.998 for a 30 day month. However, the estimated probability that a brood lost
Table 3 Results of individual year models to test whether the number of fledged chicks was dependent on clutch initiation date and nest type

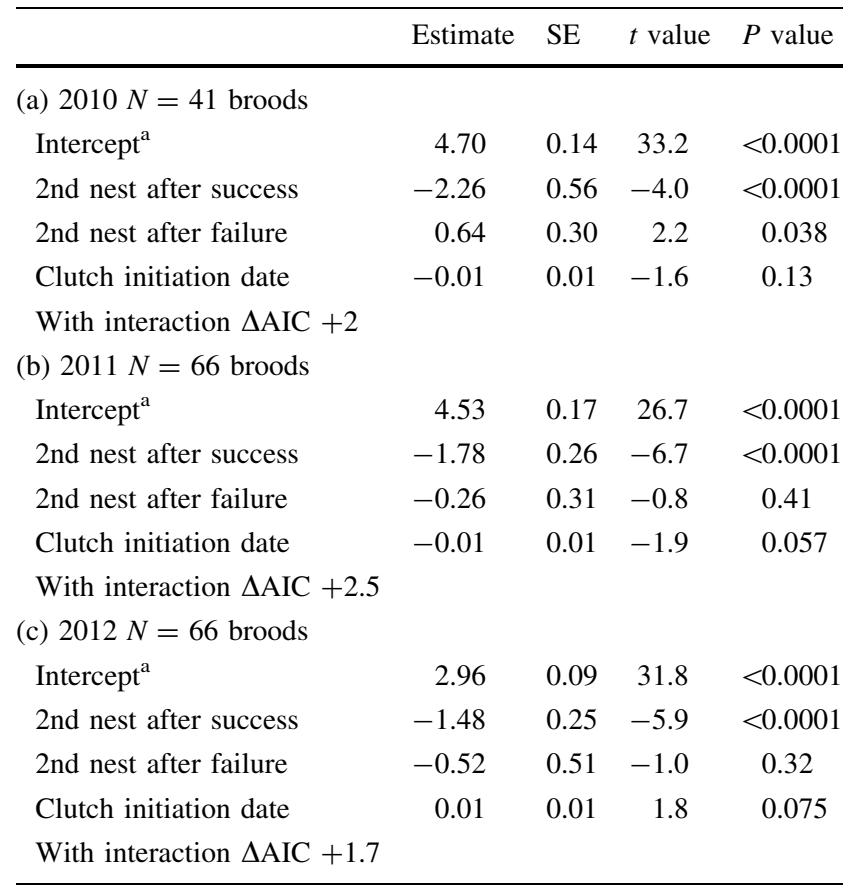

${ }^{a}$ First nest was set to the intercept

a fledged chick in the first month increased from $\sim 0.05$ at the start of the season to 0.85 at the end, and this was independent of year and nest type (Table 4; Fig. 5). Including male identity as a random effect increased the power of the model in Table 4, contributing $11.4 \%$ additional variance and increased the parameter estimate for clutch initiation date slightly to $0.06 \pm 0.02$.

Overall renesting probability was significantly different in all 3 years $\left(26,48\right.$, and $78 \%$ renesting rate; $\chi_{2}^{2}=20.8$, $P<0.0001$; Fig. 6a). The probability that renesting occurred after a successful first nest also varied 

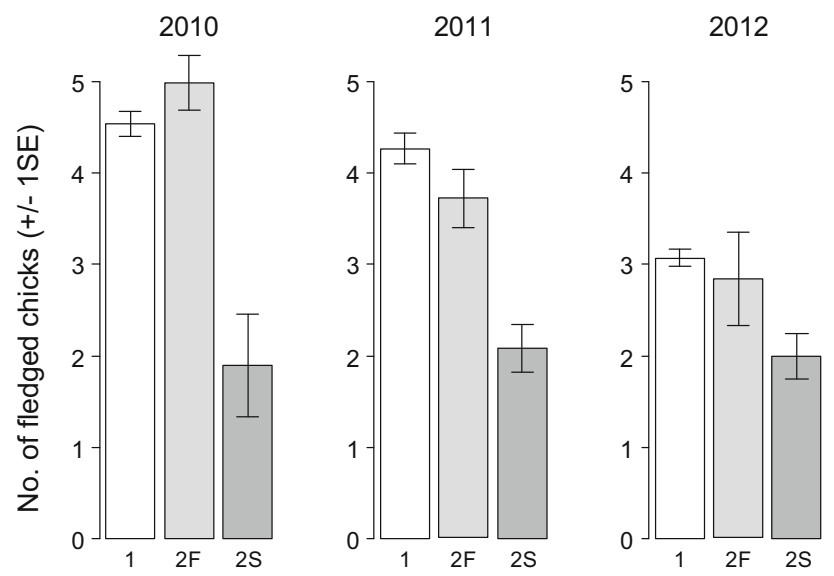

Nest Type: 1st (1), 2nd after failure (2F) or Success (2S)

Fig. 3 The number of fledged chicks produced each year with nest type. Predicted values $( \pm 1 \mathrm{SE})$ are plotted from the models in Table 3 using the median clutch initiation date for the particular year. $2010 N=41,2011 N=66,2012 N=66$ nests

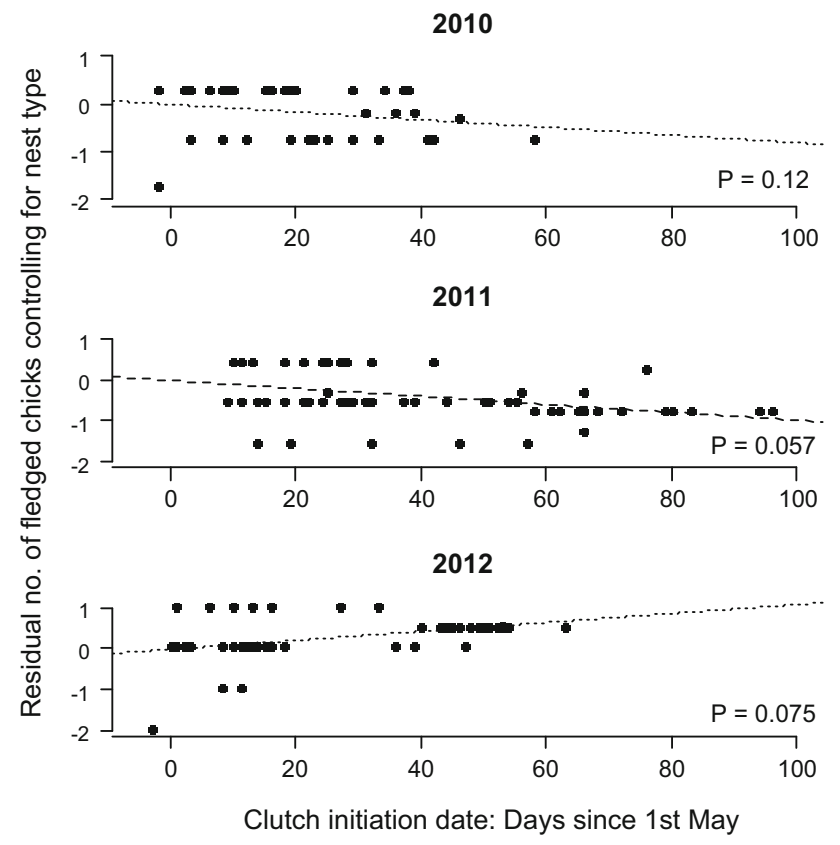

Fig. 4 The decline in the number of fledged chicks from successful nests with clutch initiation date for each year of the study. The residual number of chicks controlling for nest type (from the models in Table 3) are plotted and the best fit regression line fitted to illustrate the effects predicted in Table 3. Sample sizes as in Fig. 3 and Table 3

significantly by year: 2010 had a much lower renesting rate after success with very few second broods ( 29 versus $76 \%$ and $73 \%$ in 2011 and 2012, respectively: $\chi_{2}^{2}=6.2$, $P<0.046$ : Fig. 6b).

Overall productivity of chicks per territory (pair), alive 1 month after fledging, did not vary significantly with year $(2010, \quad 4.00 \pm 0.22 ; \quad 2011, \quad 4.00 \pm 0.27 ; \quad 2012$,
Table 4 Results of the model to test whether chick survival in the first month after fledging was dependent on year, clutch initiation date, and nest type controlling for brood size (number of fledged chicks): $N=183$ broods

\begin{tabular}{lrccc}
\hline & Estimate & SE & $z$ value & $P$ value \\
\hline Intercept & -9.84 & 1.53 & -6.4 & $<0.0001$ \\
Brood size & 1.89 & 0.30 & 6.3 & $<0.0001$ \\
Clutch initiation date & 0.05 & 0.01 & 4.0 & $<0.0001$ \\
\hline
\end{tabular}

Year and nest type were removed as non-significant terms, $\triangle \mathrm{AIC}$ +0.7 if added to the model

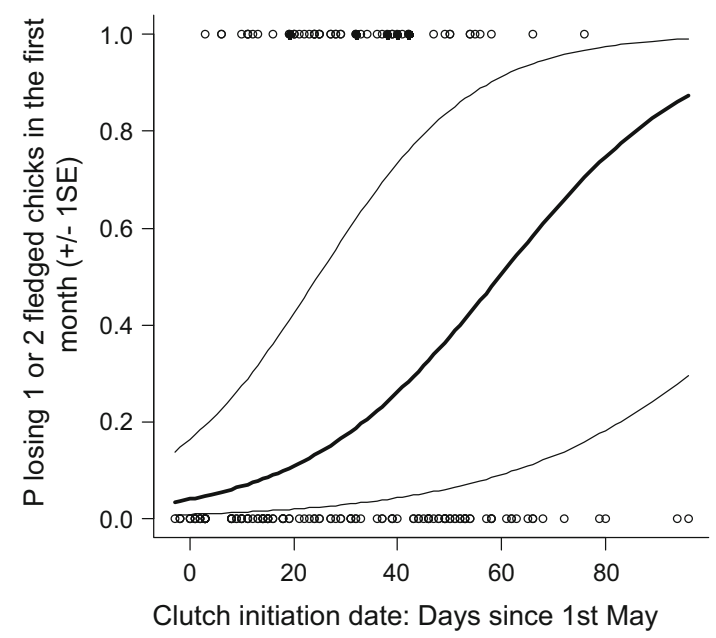

Fig. 5 The change in probability of losing one chick $(N=47$ nests, open circles) or two chicks ( $N=6$ nests, filled circles) in the first month after fledging with clutch initiation date. Mean predicted values $( \pm 1 \mathrm{SE})$ are plotted from the model in Table 4 with a mean value for brood size (number of fledged chicks) of 3.5 chicks $(N=182$ fledged broods monitored)

$3.87 \pm 0.30, F_{2,154}=0.1, P=0.87:$ Fig. 7$)$. The mean of average productivity across the $N=3$ years was $3.96 \pm 0.04$ chicks, $N=157$ territories overall. Including male identity as a random effect did not change parameter estimates or statistical significance and only explained $0.5 \%$ additional variance.

\section{Discussion}

Overall productivity was very high for a passerine (Chamberlain et al. 2009). This is particularly so because our productivity is 1 month after fledging - after the period of highest juvenile mortality-rather than estimated from fledging as with most other studies. With the lowest minimum annual survival rate recorded of 0.50 for males, 0.35 for females, and 0.34 for chicks (Xenophontos and Cresswell 2015), the minimum annual productivity of 3.87 chicks would result in a $8.3 \%$ increase in the population 

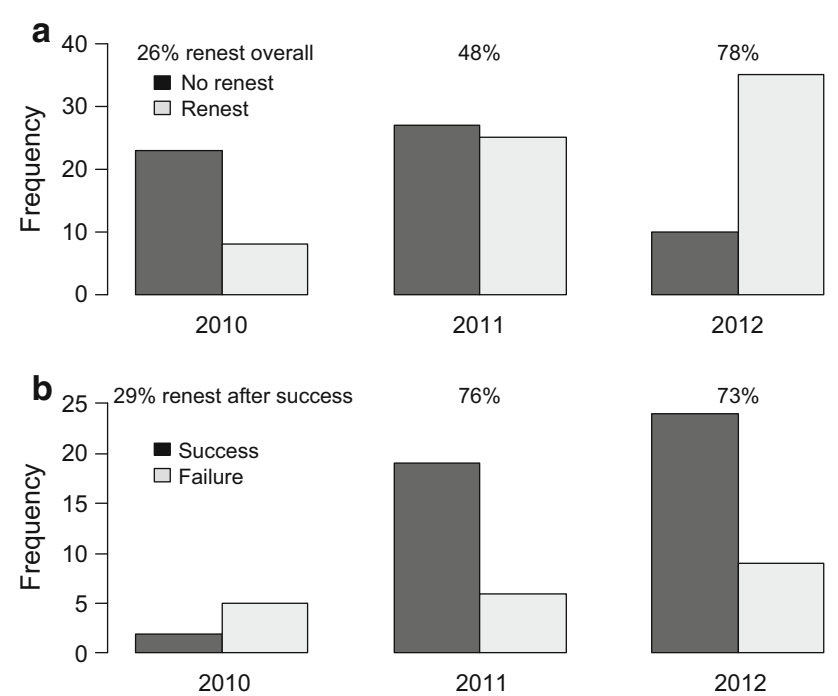

Fig. 6 Variation in annual. a Overall renesting rate regardless of nest type and $\mathbf{b}$ renest frequency after success

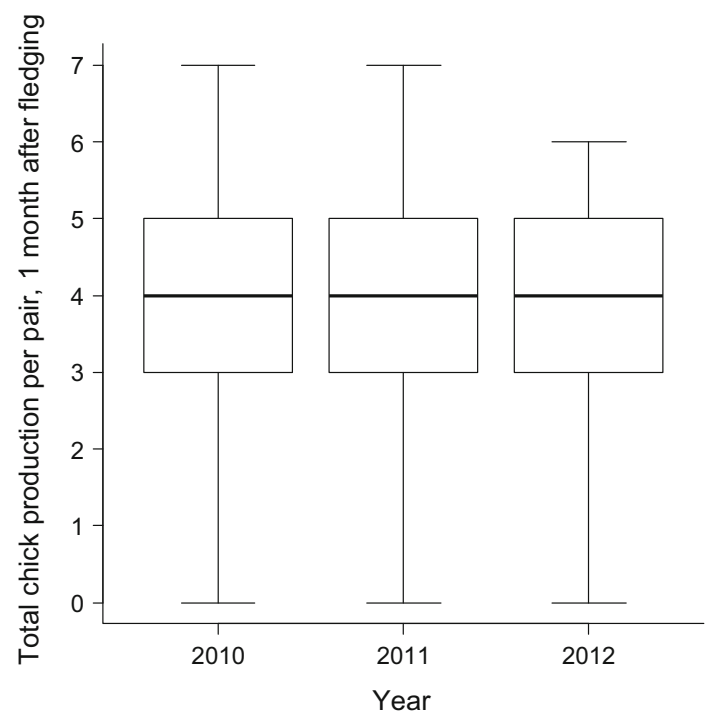

Fig. 7 Boxplot of annual variation in the number of chicks produced per pair (and that were alive 1 month after fledging)

over a year. With an average minimum survival rate for adults of $57 \%$ and for chicks of $49 \%$ (Xenophontos and Cresswell 2015), the average annual productivity would result in a $54.0 \%$ increase in the population over a year. Our study showed that although Cyprus Wheatears have a number of typical productivity characteristics: a typical clutch size, a seasonal decline in clutch size, and high renesting probability if the first nest was unsuccessful, they also have a number of atypical productivity characteristics: high nest survival, particularly in the nestling and postfledgling stage (although data are lacking for many species particularly for post-fledging survival), and a highly variable re-nesting probability after success. We discuss these characteristics in detail below.

Cyprus Wheatears had a clutch size of five for their first nests and this declined slightly with clutch initiation date. This was probably substantially lower for second nests (a decrease of c. two eggs) independently of clutch initiation date, as estimated from the number of chicks fledged. A clutch size of five is typical for similar passerines that attempt second broods, for example, the Northern Wheatear Oenanthe oenanthe (Hussell et al. 2014). The observed seasonal decline in clutch size is probably a response to food availability (e.g. Rowe et al. 1994; Brommer et al. 2002), with conditions for producing offspring deteriorating after a peak of food availability in the spring (although we have no data in this study to test this). Furthermore, the observed decline in clutch size with date may be related to increasing temperature increasing the activity, and so predation risk from snakes (Weatherhead and Blouin-Demers 2004; DeGregorio et al. 2014) and lizards, so reducing the value of larger clutches later in the season (Bennett and Owens 2002), but again we have no data in the study to test this. A lower clutch size for second broods is typical for passerines, for example, several studies of Great Tit Parus major populations have shown a decline through the breeding season (e.g. Verboven and Verhulst 1996).

Daily nest survival was relatively high for Cyprus Wheatears compared to most other passerine species (e.g. Schill and Yahner 2009; Willson and Gende 2000): when a nest failed, however, this was usually due to predation. Nest predation is an important cause of nest failure in birds (Lack 1954), so much so that nest predation risk has been shown to be an important factor in shaping avian breeding habitat preferences and life-history strategies to reduce predator impacts on nestling survival (Martin 1995). The high survival rates we found are equivalent to hole nesters, nesting in optimal often anti-predation designed cavities (Martin and Pingjun 1992). Cyprus Wheatears nest in narrow crevices or in tunnels, under or between rocks, which must provide a large degree of protection from nest predators.

Daily nest survival in Cyprus Wheatears was higher during nestling stage compared to egg stage. Many other studies have shown variation with nest stage, for example, Suarez and Manrique (1992) showed high nestling mortality rates varying with nest stages and date for Mediterranean Shrub Steppe Passerines including the Black-eared Wheatear Oenanthe hispanica. Most studies have, however, found that the stage associated with the highest mortality was the noisy and "busier" nestling stage (Skutch 1949). Nests may experience higher predation after chicks have hatched than when eggs are present, because parental activity may be a cue to predators for the location of the nest (Young 1963). For example, Grant et al. (2005) 
showed survival rates were lowest during incubation in Clay-coloured Sparrows Spizella pallida and Vesper Sparrows Pooecetes gramineus. One possible explanation for our contrary results is that they are due to lizard predation-that can effectively eat small eggs, but that then do not preferentially target chicks because they do not hunt by sight or noise, or find chicks too large to eat. The endemic lizard subspecies, the Cyprus Agamid Stellioagama stellio cypriaca is very common on Cyprus and lives in a variety of habitats distributed along all altitudinal levels, and has been frequently observed at the study site. However, agamids are large lizards that eat most things and Hodar et al. (1996) studied the diet of the similar Ocellated Lizard Lacerta lepida and found that they took Thekla Lark $G a$ lerida theklae nestlings.

Nest survival did not vary between years or nesting attempts or with clutch initiation date, suggesting that seasonal changes in predator suites or behaviour or prey switching were not important. Both Agamid Lizards and European Jays are well known predators of eggs and chicks (e.g. Weidinger 2010; Kopan and Yomtov 1982). Both species' breeding periods coincide with the Cyprus Wheatear's breeding cycle, and they both had high population abundance in the study area. But specific identification of nest predators is lacking, and although, for example, Jays and lizards were seen in the close vicinity of many nests, we have no direct evidence that any nest was taken by a Jay or a lizard.

Survival of chicks in the first month after fledging was very high. Other studies have shown low rates of survival in relation to post-fledging stage of passerines: Cox et al. (2014) showed generally that fledgling age was a strong predictor of survival, with the highest mortality occurring during the first 3 weeks after fledging. For example, in Barn Swallows Hirundo rustica, juvenile survival in the first 3 weeks post-fledging was only 0.32, whereas after this period adults and juveniles had the same high survival of 0.96 (Grüebler et al. 2014). Predation is usually the reason for low survival immediately post-fledging (e.g. Anders et al. 1997; Kershner et al. 2004). A possible explanation for our contrasting result is the absence of aerial predators such as Sparrowhawks, which are extremely rare breeders on Cyprus (Flint and Stewart 1992). Sparrowhawks were never seen at Troodos during more than $500 \mathrm{~h}$ over 4 years at the study site by WC, an experienced observer of sparrowhawks. Sparrowhawks are responsible for much of the mortality of passerines post fledging (Newton 1986). Other studies of species on islands that lack mainland predators (although there are many other predators on Cyprus) are lacking, but the few available also show high post fledging survival rates in other passerines (e.g. Brouwer et al. 2006). Duration of parental care was unlikely to be a significant factor because this varied greatly between years (unpublished data) with nearly twice the length of post-fledging feeding in 2010 not resulting in any clear difference in the proportion of a brood surviving.

Renesting probability after failure of first nests was high and not particularly variable. This makes sense because failures are mostly "accidents" involving encounters with nest predators or loss of a partner: a bird should continue breeding afterwards because the strategic reason for breeding has not been modified. In contrast, renesting probability after the first successful nest was highly variable within and between years. Multiple breeding events in a year can greatly enhance productivity. For example, Nagy and Holmes (2005) showed that $53 \%$ of female Black-throated Blue Warblers Dendroica caerulescens with successful first nests laid a second clutch and were thus double-brooded, effectively increasing productivity by half. Clutch initiation date, and consequently, food availability are likely to be the determinants of the occurrence of double brooding. Cyprus Wheatears should have a second brood if possible unless there are trade-offs in the survival of the first brood (i.e. reduced duration of parental care-which occurs varying from 2 weeks to over 4 weeks, unpublished data) or in the survival of adults (Xenophontos and Cresswell 2015). We have a limited number of years with which to examine this, but there was no obvious coincidence between lower juvenile or adult survival and the occurrence of a second brood (unpublished data). Adults may, however, always invest a particular amount in their offspring whether entirely in their first brood or divided amongst a first and second brood and so there may be no survival trade-off for adults.

One hypothesis to account for variable probability of double brooding in Cyprus Wheatears is variable temperature, which will affect food supply. Studies on, for example, Great Tits have verified that first egg date (Forchhammer et al. 1998), clutch size (Perrins and McCleery 1989), first incubation date (van Balen 1973), incubation scheduling (Cresswell and McCleery 2003), and hatch date (Winkel and Hudde 1997) can all be varied with temperature. In Cyprus Wheatears, it is likely to be high temperatures mid- and late summer that terminate breeding. We only have 3 years of data, but we noted that 2010 had the lowest renesting rate after success: this effectively resulted in that year being single-brooded and the other 2 years being double-brooded. The implication is that environmental conditions were substantially different in 2010. Temperature data for 2010 (unpublished data) show that this was a particularly warm, early year suggesting that it may be high temperatures that affect availability of food for chicks in second broods. Analysis of the phenology of breeding with temperature will be the subject of further paper from this study. 
Overall, the Cyprus Wheatear showed unusually high productivity associated with low rates of nest and postfledging predation and likely facultative double brooding. The species clearly shows that migrants breeding in Europe that winter in sub-Saharan Africa can achieve high productivity while also showing high survival. Both are very likely related to very favourable conditions (probably food availability - although this remains to be investigated) and the absence of predation risk on the study site. Other long distance migrant passerine species that also have relatively high adult survival rate and high productivity are nonetheless declining (Newton 2004; Vickery et al. 2014). We know almost nothing about post-fledging mortality for many of these species, however, and so this may well a factor accounting for the difference. Where post-fledging mortality has been measured (e.g. Anders et al. 1997; Eng et al. 2011; Tome and Denac 2012; Grüebler et al. 2014), this is invariably high further suggesting that the postfledging stage may be crucial to the population dynamics of Palearctic migrants.

Open Access This article is distributed under the terms of the Creative Commons Attribution 4.0 International License (http://crea tivecommons.org/licenses/by/4.0/), which permits unrestricted use, distribution, and reproduction in any medium, provided you give appropriate credit to the original author(s) and the source, provide a link to the Creative Commons license, and indicate if changes were made.

\section{References}

Anders AD, Dearborn DC, Faaborg J, Thompson FR (1997) Juvenile survival in a population of neotropical migrant birds. Conserv Biol 11:698-707

Bennett PM, Owens IPF (2002) Evolutionary ecology of birds: life histories, mating systems and extinction. Oxford University Press, Oxford

Brommer JE, Pietiainen H, Kokko H (2002) Cyclic variation in seasonal recruitment and the evolution of the seasonal decline in Ural owl clutch size. Proc R Soc Lond B Biol 269:647-654

Brouwer L, Richardson DS, Eikenaar C, Komdeur J (2006) The role of group size and environmental factors on survival in a cooperatively breeding tropical passerine. J Anim Ecol 75:1321-1329

Burhans DE, Dearborn D, Thompson FR, Faaborg J (2002) Factors affecting predation at songbird nests in old fields. J Wildl Manag 66:240-249

Burnham KP, Anderson DR (2002) Model selection and multimodel inference: a practical information-theoretic approach. Springer, New York

Chamberlain DE, Cannon AR, Toms MP, Leech DI, Hatchwell BJ, Gaston KJ (2009) Avian productivity in urban landscapes: a review and meta-analysis. Ibis 151:1-18

Collar N (2005) Cyprus Wheatear (Oenanthe cypriaca). In: Del Hoyo J, Elliott A, Sargatal J, Christie DA, de Juana E (eds) Handbook of the birds of the world alive. Lynx Edicions, Barcelona (retrieved from http://www.hbw.com/node/58544 on 30 October 2015)
Cox WA, Thompson FR, Cox AS, Faaborg J (2014) Post-fledging survival in passerine birds and the value of post-fledging studies to conservation. J Wildl Manag 78:183-193

Crawley MJ (2007) The R book. Wiley, Chichester

Cresswell W (1997) Nest predation rates and nest detectability in different stages of breeding in Blackbirds Turdus merula. J Avian Biol 28:296-302

Cresswell W, McCleery RH (2003) How great tits maintain synchronisation of their hatch date with food supply in response to long term variability in temperature. J Anim Ecol 72:356-366

DeGregorio BA, Chiavacci SJ, Weatherhead PJ, Willson JD, Benson TJ, Sperry JH (2014) Snake predation on North American bird nests: culprits, patterns and future directions. J Avian Biol 45:325-333

Eng ML, Stutchbury BJM, Burke DM, Elliott KA (2011) Influence of forest management on pre- and post-fledging productivity of a Neotropical migratory songbird in a highly fragmented landscape. Can J For Res Rev Canadienne De Recherche Forestiere 41:2009-2019

Flint PR, Stewart PF (1992) The birds of Cyprus. British Ornithologists Union, Tring, Herts

Forchhammer MC, Post E, Stenseth NC (1998) Breeding phenology and climate. Nature 391:29-30

Grant TA, Shaffer TL, Madden EM, Pietz PJ (2005) Time-specific variation in passerine nest survival: new insights into old questions. Auk 122:661-672

Grüebler MU, Korner-Nievergelt F, Naef-Daenzer B (2014) Equal nonbreeding period survival in adults and juveniles of a longdistant migrant bird. Ecol Evol 4:756-765

Hazler KR (2004) Mayfield logistic regression: a practical approach for the analysis of nest survival. Auk 121:707-716

Hodar JA, Campos F, Rosales BA (1996) Trophic ecology of the Ocellated Lizard Lacerta lepida in an arid zone of southern Spain: relationships with availability and daily activity of prey. J Arid Environ 33:95-107

Hussell DJT, Bairlein F, Dunn EH (2014) Double brooding by the Northern Wheatear on Baffin Island. Arctic 67:167-172

Kershner EL, Walk JW, Warner RE (2004) Postfledging movements and survival of juvenile eastern meadowlarks (Sturnella magna) in Illinois. Auk 121:1146-1154

Kopan R, Yomtov Y (1982) Agama stellio (Reptilia, Sauria) feeding on avian eggs and chicks. Isr J Zool 31:159-160

Lack D (1947) The significance of clutch size, parts 1 and 2. Ibis 89:302-352

Lack D (1954) The natural regulation of animal numbers. Clarendon, Oxford

Lack D (1968) Ecological adaptions for breeding in birds. Methuen, London

Martin TE (1995) Avian life history evolution in relation to nest sites, nest predation and food. Ecol Monogr 65:101-127

Martin TE, Pingjun LI (1992) Life history traits of open- vs cavitynesting birds. Ecology 73:579-592

Mayfield H (1961) Nesting success calculated from exposure. Wilson Bull 73:255-261

Nagy LR, Holmes RT (2005) To double-brood or not? Individual variation in the reproductive effort in black-throated blue warblers (Dendroica caerulescens). Auk 122:902-914

Newton I (1986) The sparrowhawk. Poyser, Calton

Newton I (1998) Population limitation in birds. Academic Press, London

Newton I (2004) Population limitation in migrants. Ibis 146:197-226

Perrins CM (1970) The timing of birds' breeding season. Ibis 112:242-255

Perrins CM, McCleery RH (1989) Laying dates and clutch size in the Great Tit. Wilson Bull 101:236-253 
Randler C, Teichmann C, Pentzold S (2010) Breeding habitat preference and foraging of the Cyprus Wheatear Oenanthe cypriaca and niche partitioning in comparison with migrant Oenanthe species on Cyprus. J Ornithol 151:113-121

Rowe L, Ludwig D, Schluter D (1994) Time, condition and the seasonal decline of avian clutch size. Am Nat 143:698-772

Schaub R, Mumme RL, Woolfenden GE (1992) Predation on the eggs and nestlings of Florida scrub jays. Auk 109:585-593

Schill KL, Yahner RH (2009) Nest-site selection and nest survival of early successional birds in central Pennsylvania. Wilson $\mathrm{J}$ Ornithol 121:476-484

Shaffer TL (2004) A unified approach to analyzing nest success. Auk 121:526-540

Skutch AF (1949) Do tropical birds rear as many young as they can nourish. Ibis 91:430-458

Suarez F, Manrique J (1992) Low breeding success in Mediterranean shrubsteppe passerines-Thekla lark Galerida theklae, lesser short-toed lark Calandrella rufescens, and black-eared wheatear Oenanthe hispanica. Ornis Scand 23:24-28

Tome D, Denac D (2012) Survival and development of predator avoidance in the post-fledging period of the Whinchat (Saxicola rubetra): consequences for conservation measures. J Ornithol 153:131-138

van Balen JH (1973) A comparative study of the breeding ecology of the great tit Parus major in different habitats. Ardea 61:1-93
Verboven N, Verhulst S (1996) Seasonal variation in the incidence of double broods: the date hypothesis fits better than the quality hypothesis. J Anim Ecol 65:264-273

Vickery JA, Ewing SR, Smith KW, Pain DJ, Bairlein F, Skorpilova J, Gregory RD (2014) The decline of Afro-Palaearctic migrants and an assessment of potential causes. Ibis 156:1-22

Weatherhead PJ, Blouin-Demers G (2004) Understanding avian nest predation: why ornithologists should study snakes. J Avian Biol $35: 185-190$

Weidinger K (2010) Foraging behaviour of nest predators at open-cup nests of woodland passerines. J Ornithol 151:729-735

Willson MF, Gende SM (2000) Nesting success of forest birds in southeast Alaska and adjacent Canada. Condor 102:314-324

Winkel W, Hudde H (1997) Long-term trends in reproductive traits of tits (Parus major, P. caeruleus) and pied flycatcher (Ficedula hypoleuca). J Avian Biol 28:187-190

Xenophontos M, Cresswell W (2015) Survival and dispersal of the Cyprus Wheatear (Oenanthe cypriaca), an endemic migrant. $\mathrm{J}$ Ornith (in press)

Young H (1963) Age-specific mortality in the eggs and nestlings of blackbirds. Auk 80:145-155 